\title{
創外固定された脛骨骨折部の力学的特性の推定法に関する研究*
}

\author{
尾田十八*1, 坂 本二郎*1, 酒井卓 巳*2 $^{* 2}$ \\ 末 吉 泰 信*3, 富田勝 郎*4
}

\section{A Study on Mechanical Property Evaluation of Bone Fracture in Tibia with External Fixator}

\author{
Juhachi ODA, Jiro SAKAMOTO, Takumi SAKAI, \\ Yasunobu SUEYOSHI and Katsuro TOMITA
}

\begin{abstract}
External fixation technique is a convenient treatment for wide clinical use such as bone fracture. In this treatment, it is important to make decision when the external fixation device is detached and the patient start rehabilitation, in order to achieve early healing. Evaluation techniques for bone healing level can offer useful suggestions to the doctor making decision. Thus, we develop an evaluation method of mechanical properties of callus on bone fracture fixed by external fixator. In the method, strains are measured using strain gauges which are attached to some parts of the fixator fixing bone fracture with a certain loading. The strains are inputted to a mathematical or computational model of the fixator and bone, then the callus properties are evaluated inversely. We consider a case of transverse plane fracture of human tibia with external fixator, and apply the evaluation method using an experimental model, a finite element model and a model based on beam theory. Efficiency of the proposed method is discussed from the results.
\end{abstract}

Key Words: Biomechanics, Finite Element Method, Medical Engineering, Inverse Problem, External Fixator, Bone Fracture

\section{1. 緒 言}

骨折部に直接器具を埋め込んで骨折を固定する創内 固定と言われる手術法に対し，ビンのみを骨折部周辺 に刺入し，それを介して体外少ら骨折を固定寸る創外 固定といおれる方法がある。創外固定は，骨折部を大 きく切開する必要がなく，また体外から容易に骨折ひ 修復ができると言った利点から，普及しつつある整形 外科治療の一つである。この治療法では，患者のリ八 ビリ開始時期や創外固定器の取り外し時期をどうやっ て確定するかが重要であり，そのために骨折部の修復 に伴う力学的特性の変化を把握することが必要とされ 万.

骨折部の力学的特性ひ把握は, 患部への悪影響を考 慮し、非侵襲的に行われることが望ましいが，現在け ところ考え得る手法として，レントゲン写真やC Tな どの画像情報に基ゔく手法いやアコースティックエ ミッション $(\mathrm{AE})$ 法による手法(1)(2)などが挙げられる。 臨床的には画像情報に基づいた骨折部の治瘉評価が最 も一般的である。この方法は，画像から求めた骨密度 や骨塩量をもとに間接的に骨折部の治瘾状況を推察す るといったもので，医師の勘や経験に頼るところが多 く, 必げしも定量的な評価とはなっていない. AE法

* 原稍受付 1997 年 11 月 4 日

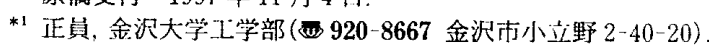

*2 准員, (株) 金沃村田製作所( - 920-2101 石川県石川郡鶴来町 兽谷町于 18 ).

*3 国立金沢病院 (画9200935 金沢市不引 3-1-1).

*4 金沢大学䀢学部 (画 920-8641 金沢市宝町 13-1).
は，骨折部の微視的破壊によって発生する弾性波を測 定子ることにより骨折部の強度を推定するものである が,骨折部が柔らかい状態の際には効果がないこと,ま た骨折部に微視的破壊を起こす危険性などから，必ず しも望ましい手法ではない，上記の手法は，骨折一般 に対して，その治癒回復を評価するものであるが，対 象を創外固定を用いた治療に限定した場合，創外固定 器に発生するひずみによって骨折部の力学的特性を推 定打る方法が考えられる(3)(1)(5).西村らは死体骨を用い た実験により，その可能性を示唆している．先の二つ の方法とこれらの方法を比較した場合, 骨折部の力学 的特性変化の影響を最も直接的に把握できるという観 点から, 創外固定器のひずみに基づく手法が最も望ま しいと考えられる.

そこで本研究では, 創外固定器に発生するひずみを 測定し、これをもとに骨折部の力学的特性を逆解析的 に推定する方法について検討寸る。ここでは，まず創 外固定された骨折モデルを考え，これに負荷が作用し た場合の骨折部および創外固定器に発生寸る応力やひ ずみ状態を実験とFEM解析により求める。，そして，実 験とFEM解析のそれぞれについて荷重とひずみとの関 倸を求め, それらの結果の比較から，本手法や解析モ デルの妥当性を検討する.さらに，骨折部の材料特性 变化させた場合, それが創外固定器に発生するひず 办に及ぼす影響を評価することでここで想定してい る推定手法が有効かどうかを検討する。 


\section{2. 骨折の力学的特性の推定法}

\section{$2 \cdot 1$ 推定法のモデル}

本研究では，図 1 に示すように脛骨中央で起こっ た開放型の骨折を 4 本のピンによって挟み込むよう に固定する場合を想定する．実際の骨折では治療の 初期段階で, 骨折した部分に仮骨と呼ばれる軟組織 状のものが形成される．この仮骨は，骨折治瘾の進 行に伴い徐々に固くなり, 通常の骨と同じ力学的特 性を有するまでに回復した時点で骨折の修復が完了 する. 本研究ではこれらに対応した骨折モデルと骨 折の治癒後を想定した非骨折モデルを考える.

なお，力学的特性の推定の方法として以下の二つを 考えた.すなわち骨折部に既知の荷重が負荷する場合 を想定し, モデルに外荷重を負荷させることで創外固 定器に発生するひずみを得る方法と, 創外固定器に取 り付けた骨延長器によってモデルに強制変位を与える ことでひずみを得る方法である，以下では，それぞれ を開放系の場合および閉鎖系の場合と呼ぶことにする。

\section{$2 \cdot 2$ 開放系（外荷重負荷）の埥合}

\section{$2 \cdot 2 \cdot 1$ 実験方法}

本実験で使用した創外固定器 (Smi th\&Nephue 社製, HexFix）は，大きくはステム部，ユニバーサルジョイ ント部，および刺入ピンから構成される(図 1)。この 創外固定器をすべての実験モデルで使用した. 脛骨部 については, 多孔質のポリウレタンフォームからなる 模擬骨を使用した.この関節面に相当する両端を水平 に切除した後, 創外固定器を取り付ける. 模擬骨の下 端面を固定し, 上端面に荷重試験器（島津製作所AGS5000B) によって試験速度 $0.1 \mathrm{~mm} / \mathrm{min}$ で圧縮方向に最大 $98 \mathrm{~N}$ まで負荷させた。実験モデルを図 2 に示す。

ひずみの測定䇢所は図 2 に示すように創外固定器の ステム部中央の内外側面とした. 骨折部に対して外側 の測定点を SG1, 内側の測定点をSG2 と定め, ステムの 軸方向に沿ってひずみグージを貼付した。

また実験モデルは，骨折モデルとして，骨折後形成 される仮骨に相当する材料としてシリコンゴム，およ びスポンジ状のポリウレタンフォームの 2 種類を用意 した. それぞれの実験モデルをMode11，およびModel2 と呼ぶことにする。また非骨折モデルをMode13 と呼 ぶ. 創外固定器, 骨部, および仮骨部の材料特性值を 表 1 に示す.

\subsubsection{FEM 解析}

本研究で用いた創外固定器は 2 個のニニバーサル ジョイント，4本のピンで構成されているが，それぞ れは堅固につなぎ合わされている.解析モデルではピ ンの骨部への挿入部分に両者のゆるみがないものと考 え，モデル全体を連続体とした。また骨部と仮骨部の 境界も連続しているものと仮定した。

本研究で作成した創外固定された脛骨の有限要素分

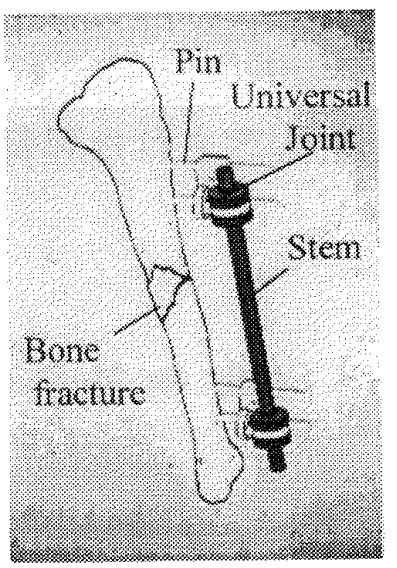

Fig. 1 External fixator for tibia fracture by Hex-Fix (Smith\&Nephue, Inc.)
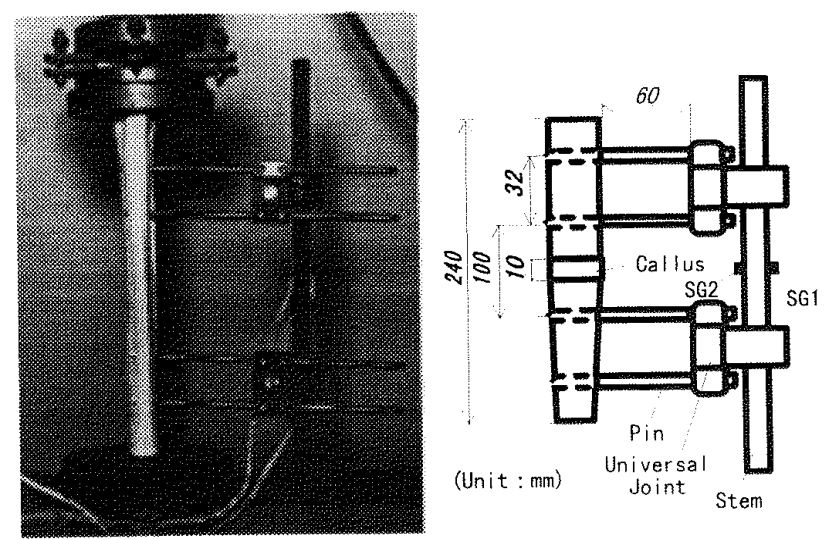

Fig. 2 Experimental model

Table. 1 Material properties

\begin{tabular}{|c|c|c|r|r|}
\hline \multicolumn{2}{|l|}{} & $\begin{array}{c}\text { Young's modulus } \\
\text { (MPa) }\end{array}$ & $\begin{array}{c}\text { Poisson's } \\
\text { ratio }\end{array}$ \\
\hline $\begin{array}{c}\text { External } \\
\text { fixator }\end{array}$ & Stem,Universal joint & Aluminum & 71000 & 0.34 \\
\hline Tibia & Pin & Stainiess steel & 180000 & 0.30 \\
\hline Caltus & & Polyurethan & 271 & 0.32 \\
& Model 1 & Silicon rubber & 0.834 & 0.49 \\
& Model 2 & Polyurethan & 19.6 & 0.32 \\
\hline
\end{tabular}

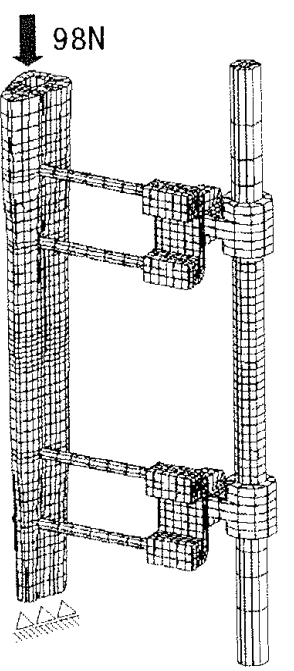

Fig. 3 Finite element model 
割図在図 3 に示与。節点数は 7437 ，要素数は5226で, 要素に汢8 節点 6 面体要素を用いた。境界条件は，骨 部下端の節点全てを 3 万向に変位拘束した。荷重とし て骨部上端の節点に，合計で $98 \mathrm{~N}$ の圧縮荷重が作用寸 るような節点力を与え, 線形弾性解析を行った。計算 に用いた材料特性值は表 1 に示寸とおりである。なお 計算には汎用有限要素法プログラムである MARC (MARC Analysis Research Co.) を使用した.

\section{$2 \cdot 2 \cdot 3$ はり理論による計第}

骨折部ひ力学的特性を推定方るには，ステムに発生 するひず的の解析を数多く繰り返扵必要があることか ら，上り簢便な解析法が望ましい，そこで創外固定器 と脛骨を図 4 に示すようなフレームモデルに近似し， ひずみを評価する方法を考えた。ここではモデルの簢 単化のため，ビン部を一本のは仕りとし，また骨部を単 純な円筒に近似した。各部の寸法の記号とその值，断 面積および断面二次モーメントを表 2 に示吉。計算で 用いた各部の材料特性値はFEM解析で用いたものと同 様である。以下に計算過程を示寸。

脛骨に荷重Pが作用した場合, 創外固定器と骨折部 に分担される荷重をそれぞれ $P_{1}, P_{2}\left(P=P_{1}+P_{2}\right)$ とし，図 40 上うに $\mathrm{AC}$ 部を片持ちげり，CD部を両端単 純支持の段付き代りとして考える。

$A C$ 部に执けるC 点での $\mathrm{P}$ 、によるたわ角 $\theta$ ，执 びたすみw，长次式に示扵。

$$
\begin{aligned}
& \theta_{1}=\frac{1}{E_{2} I_{2}}\left(-M_{1} l_{2}+\frac{P_{1}}{2} l_{2}^{2}\right) \\
& w_{1}=\frac{1}{E_{2} I_{2}}\left(-\frac{M_{1}}{2} l_{2}^{2}+\frac{P_{1}}{3} l_{2}^{3}\right)
\end{aligned}
$$

CD部におけるC点でのM，によるたわ双角 $\theta_{2}$ ，およ び $\mathrm{P}_{2}$ による軸方向の変位 $\mathrm{w}_{2}$ を次式に示寸.

$$
\begin{aligned}
& \theta_{2}=\left(\frac{l_{3}}{E_{3} I_{3}}+\frac{l_{4}}{2 E_{4} I_{4}}\right) M_{1} \\
& w_{2}=\left(\frac{l_{3}}{A_{3} E_{3}}+\frac{l_{4}}{2 A_{4} E_{4}}\right) P_{2}
\end{aligned}
$$

$A B$ 部の曲げによるし点のたわみ成分 $w_{3,}$, および $\mathrm{P}$ ， によるA点の軸方向変位 $\mathrm{W}_{4}$ を次式に示寸.

$$
\begin{aligned}
& w_{3}=\frac{\left(P_{1} l_{2}-M_{1}\right) l_{1} l_{2}}{2 E_{1} I_{1}} \\
& w_{4}=\frac{l_{1}}{2 A_{1} E_{1}} P_{1}
\end{aligned}
$$

C点にお汀る回転角と, 変位心適合条件から, 武(1) (6)以测の関係が成り立つ.

$$
\begin{aligned}
& (1)-(3)=0 \\
& (2)+(5)+(6)=(4)
\end{aligned}
$$

上式を整理すると次の連立方程式が得られる。

$$
\left\{\begin{array}{l}
a M_{1}+b P_{1}=0 \\
c M_{1}+d P_{1}=e
\end{array}\right.
$$

ここで,

$$
\begin{aligned}
& a=\frac{l_{2}}{E_{2} I_{2}}+\frac{l_{3}}{E_{3} I_{3}}+\frac{l_{4}}{2 E_{4} I_{4}}, b=-\frac{l_{2}^{2}}{2 E_{2} I_{2}}, \\
& c=-\frac{l_{2}^{2}}{2 E_{2} I_{2}}-\frac{l_{1} l_{2}}{2 E_{1} I_{1}}, \\
& d=\frac{l_{2}^{3}}{3 E_{2} I_{2}}+\frac{l_{1} l_{2}^{2}}{2 E_{1} I_{1}}+\frac{l_{3}}{A_{3} E_{3}}+\frac{l_{4}}{2 A_{4} E_{4}}+\frac{l_{1}}{2 A_{1} E_{1}}, \\
& e=\left(\frac{l_{3}}{A_{3} E_{3}}+\frac{l_{4}}{2 A_{4} E_{4}}\right) P
\end{aligned}
$$

である。

これを解くと，

$$
M_{1}=\frac{e}{c-\frac{a d}{b}}, P_{1}=\frac{e}{d-\frac{b c}{a}}
$$

よってステムに生ずるひずみは，

$$
\varepsilon_{z}=z \frac{P_{1} l_{2}-M_{1}}{E_{1} I_{1}}
$$

で与えられる。ここでュはステムの中立軸からひずみ を測定小る点までの距離で， $\mathrm{z}=6.9(\mathrm{~mm})$ である。

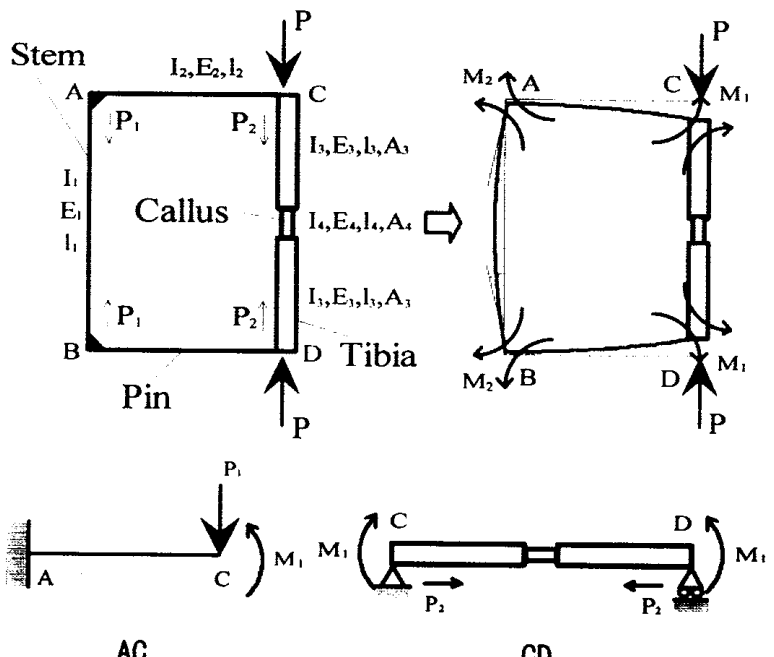

Fig. 4 Beam theory model

Table. 2 Size of beam elements

\begin{tabular}{|c|cc|r|}
\hline External fixator & Moment of inertia of area & 11 & 2200 \\
\cline { 2 - 4 } & Length & 11 & 132 \\
\hline \multirow{3}{*}{ Pins } & Moment of inertia of area & 12 & 10100 \\
\cline { 2 - 4 } & Length & 12 & 110 \\
\hline Tibia & Area & $\mathrm{A}^{3}$ & $\mathbf{4 5 0}$ \\
\hline Callus & Length & 13 & 61 \\
\cline { 2 - 4 } & Area & $\mathrm{A}^{4}$ & 450 \\
\cline { 2 - 4 } & Length & 14 & 10 \\
\hline \multicolumn{3}{|c}{} \\
\cline { 2 - 4 } & \multicolumn{2}{|c}{ Liti $/\left(\mathrm{mm}^{4}\right)$}
\end{tabular}

Unit: $:\left(\mathrm{mm}^{4}\right), /(\mathrm{mm}), A\left(\mathrm{~mm}^{2}\right)$ 


\section{$2 \cdot 3$ 閐鎖系（強制变位）の場合}

\section{$2 \cdot 3 \cdot 1$ 実験方法}

上記モデルでは，脛骨軸方向に既知の荷重を負荷し た場合を想定してきた。しかし，直立時であっても実 際に脛骨に作用する荷重は複雑で，これを同定するの は非常に困難である，方法としては，体内すなわち脛 骨に作用する荷重は未知のままにしておき，むしろ体 外すなわち創外固定器側に制御可能な負荷条件を与え る方が望ましい，そこで骨延長術等に用いられる骨延 長器を利用して, 創外固定器側に強制変位を与え, そ の際の創外固定器に発生するひずみを評価することで 骨折部の力学的特性を推定する手法を考案した.

本手法で用いた骨延長器を図 5 に示寸。この器具は 本来は骨の延長や変形の矯正などに用いるものであり， 創外固定器に取り付け, 図中右上部のつまみを回すこ とによって一回転につき $1 \mathrm{~mm}$ の割合でュニバーサル ジョイントを変位させることができるものである．

骨延長器を利用した場合の実験モデルを図 6 に示寸. 骨延長器は創外固定器のステム部上端に取り付け, 上 側のユニバーサルジョイントの上面に強制的に変位を 与える. 変位は骨折部を圧縮する方向に最大 $2 \mathrm{~mm} の$ 変

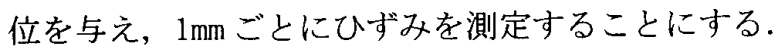

ひずみの測定䇢所は図 6 に示すように創外固定器の ステム部中央の内外側面, および一番上のピンの上下 面とした．ステムに関しては骨折部に対して外側の面

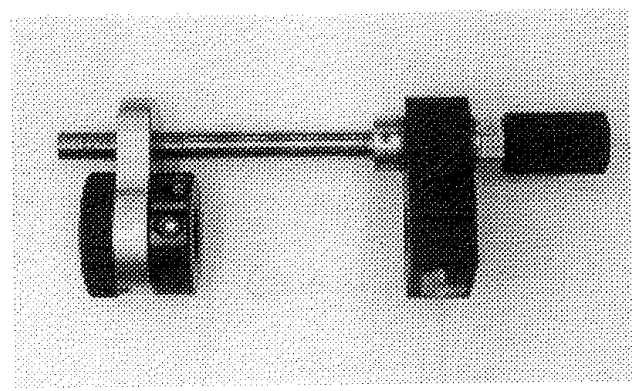

Fig. 5 Bone extender
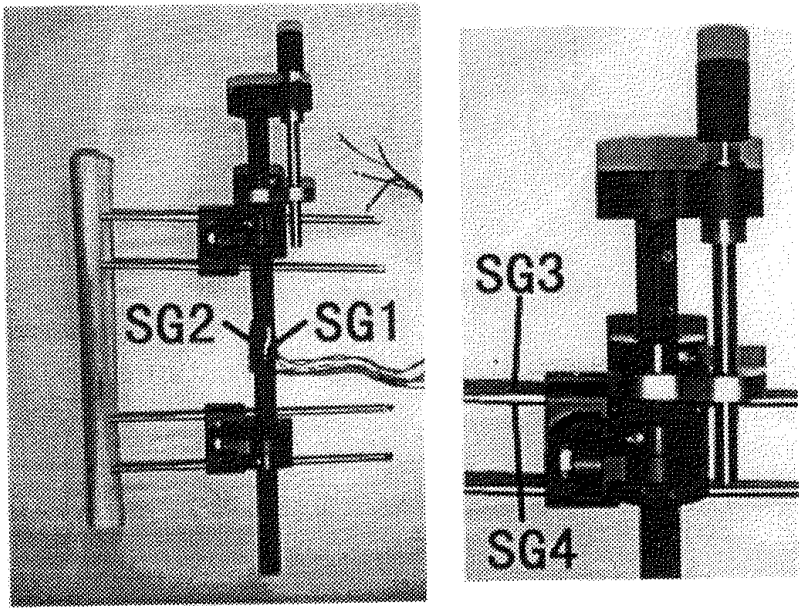

Fig. 6 Experimental model using an extender
の測定点を $\mathrm{SG} 1$, 内側の測定点を $\mathrm{SG} 2$ と定め, ステムの 軸方向に沿ってひずみゲージを貼付した．またピンに 関しては上面の測定点を $\mathrm{SG} 3$ ，下面の測定点を $\mathrm{SG} 4$ と定 め,ピンの軸方向に沿ってひずみゲージを貼付した.実 験モデルは，開放系の場合と同様に骨折の治癒過程に 対応した 3 種類のモデルを作成し，それぞれをModel 1 〜 3 と定めた.

\section{$2 \cdot 3 \cdot 2$ FEM 解析}

実験に対忘して作成した有限要素分割図を図 7 に示 す. 節点数は 8360 , 要素数は 5868 である. 境界条件は, ステム部下端の節点全てを 3 方向に変位拘束した．骨 延長器による強制变位は図に示寸 6 節点に与え, 変位 量は骨折部を圧縮する方向に $1 \mathrm{~mm}$ または $2 \mathrm{~mm}$ とした。

上部のユニバーサルジョイント部とステム部の間は, 初期状態では互いに拘束されてはいないが, 強制変位 時にはステム等が変形し,それに伴って両者が接触し， ステム部に荷重が伝達される，従って，本FEM解析モ デルでは両者の間を接触面として定義することで，接 触を考慮した解析を行った。この接触部では法線方向 のみの力のみが伝達されるものとし，す心゙り方向の摩 擦力は考えないものとした。

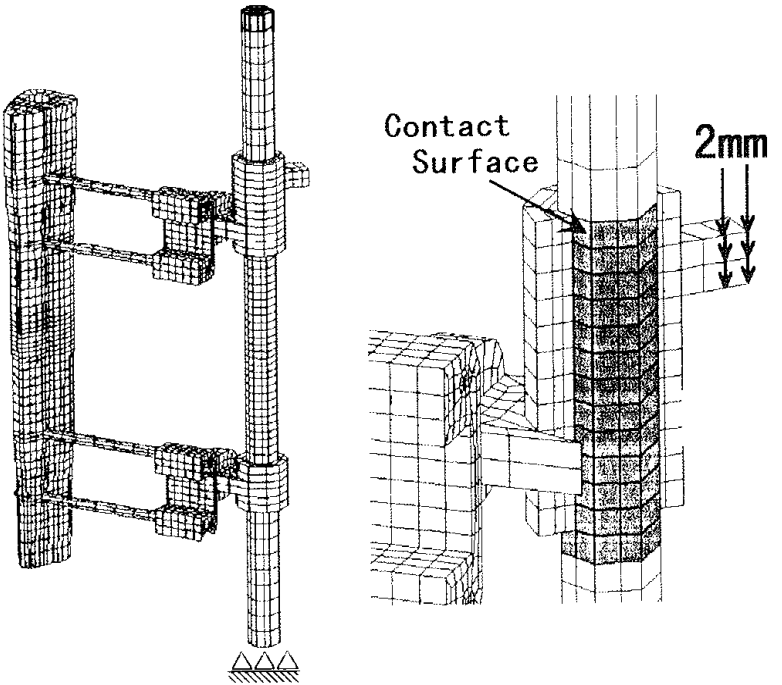

Fig. 7 Finite element model with an extender

\section{3. 推定結果とその考察}

\section{$3 \cdot 1$ 開放系（外荷重負荷）の場合}

ステム外側（SG1）および内側（SG2）に発生するひ ずみについて, 実験值, FEMによる值, およびはり理論 による值を比較したものを図 8 に示す. 非骨折モデル (Mode13) では実験，FEM解析とも発生するひずみが無 視できるほど小さいので，ここでは主に骨折モデルの Mode11 と 2 にいて比較を行う.

SG1 とSG2 とを比較すると, 実験值およびFEM值にお いて, 両者がほぼ等しい值で, 正負が逆の值を示して いることから，ステムには単純な曲げが作用している ものと考えられる.また, FEM解析值と実験值はほぼ一 
致して抢り，本研究で作成したFEVモデルは妥当なも (であると考えりれる。视理論の值については仮骨 にシリュンゴムを用いた場合(Mode1 1)に执てて特に 実験值と大きな開きが見られる。この原因の一つとし ては，注り理論に拈いて各部材の接合部名剛接と仮定 されている点泣挙げられる。末た，はり理論で汢面内 変形け办を考慮した解析となっているが，非軸対称の 形状を有子る脛骨やジョイント部以実際には 3 次元的 な変形を子ると考えられ，こけこともはり理論による 解析が他と一致しない原因として挙げられる。

骨折り治療過程を想定した計算で仕仮骨部のヤング

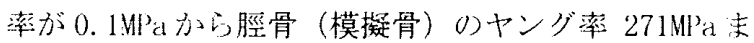
で変化子る上考え，兰れに伴いボアソン比は 0.49 〜 0. 32 末で線形に変化子るもり上仮定寸る。この際のFEM による解析結果考験值，は理論值と比較して，図 9 に示す。仮骨りヤング率が低い領域（約 10MPa 以下） ではヤング率り変化に詨して創外固定器のひずみも敏 感に変化小るが，ヤン方率が大きい領域ではひずみの

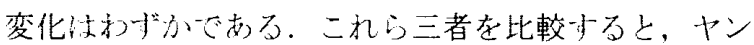
グ率が大きい領域ではどれも同じような值を示してい

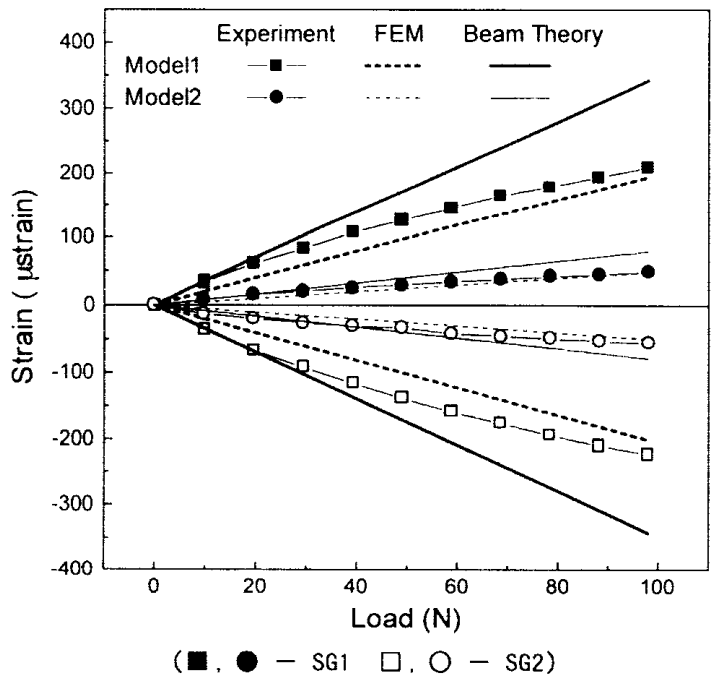

Fig. 8 Strain-load histories at SG1 obtained by experiment,. FEM and beam theory

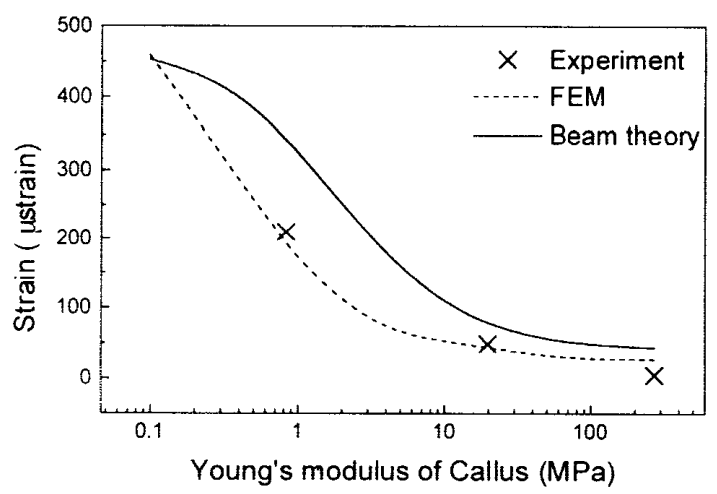

Fig. 9 Strains with changing of the callus Young's modulus
るが，ヤング率が小さい領域でははり理論による值は 他の二者よりややや大きぬの值を示している。

次に仮骨けヤング率とボアソン比を独立に変化させ た場合の影響について考える.仮骨のヤング率を0.1〜 $271 \mathrm{MPa}$, ホアソン比を $0.21 \sim 0.490$ 領域で独立に変化 させた際の創外固定器に発生卞るひず办をFEMにより 求めた。これを图10に示少。ひ-゙多の值は主としてヤ ング率の変化に依存し，ボアソン比の变化による影響 㤌あま大きくない。ただし，ヤング率が低い領域で はホホアソン比の変化がひずみに与える影響が見られ， ボアソン比が大きい注どひず值が小さくなるのおか る。こけような領域に执て仮骨部のヤング率を正確 に推定寸るには，ホアアンン比の影響を考虑技る必要が あると考えられる。

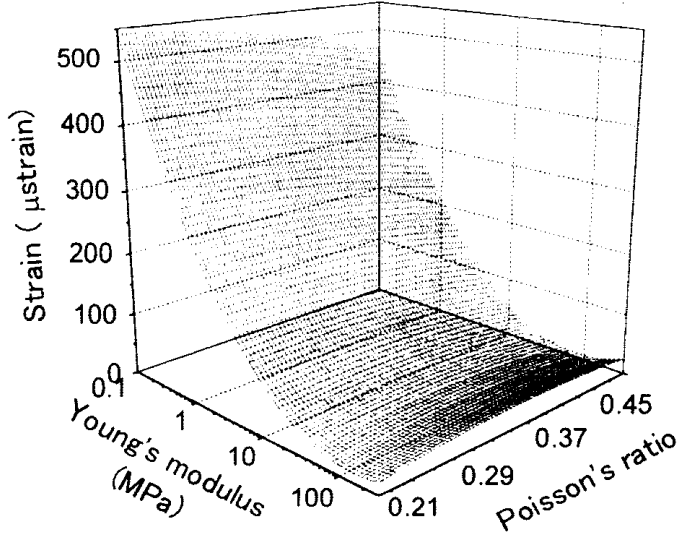

Fig. 10 Strains with changing of the callus Young's modulus and poisson's ratio

\section{$3 \cdot 2$ 閉鎖系（強制变位）の場合}

骨延長器によって $1 \mathrm{~mm}$ の強制変位を与えたときけ ModelI〜30)各部（SGI〜S(F) に発生小るひずみにつ いて，実験值とFEMによる值を比較したものを図11に 示す、いずれのモデルもビン側に生ずるひずみ（SG3 と SG4）は実験值とFEM 值でよく一致しているのに対し, ステム側に生ずるひずタ（SCil とS(2)）には両者の值に 大きな開きが見られる。これはFEMモデルにおいて接 触部の形状（ステムとジョイント間のギャップの寸法 など）によるステム部のひずみの影響が大きいことが 原因と考えられる。より精度り高い計算を行うには，接 触部形状を厳密に表した，より詳䋱なトEYモデルの作 成が必要である。

次に仮骨部の材料特性と, 創外固定器に発生一るひ ずタの関係について考える。開放系と同様に治療過程 に执いて仮骨部のヤン方率が0.1MPaから271MPaまで変 化するのに伴い, ポアソン比も $0.49 \sim 0.32$ まで変化子 ると仮定䒚る。网汭による解析結果を実験值と比較し て，图12に示寸。この場合も仮骨のヤング率が低い領 域ではヤング摔の変化に対して創外固定器のひずみも 敏感に変化标るが，ヤング率が大きい領域ではひずみ 


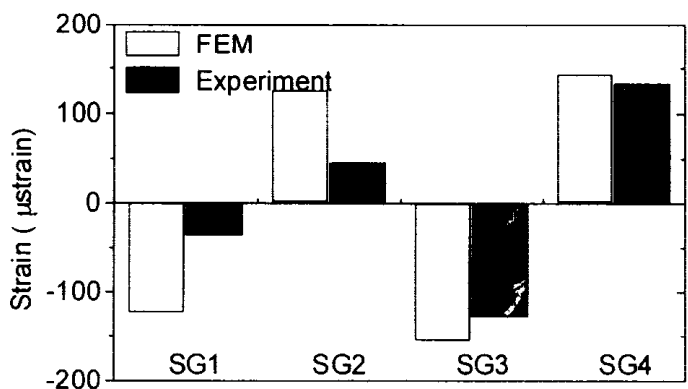

(a) Model1

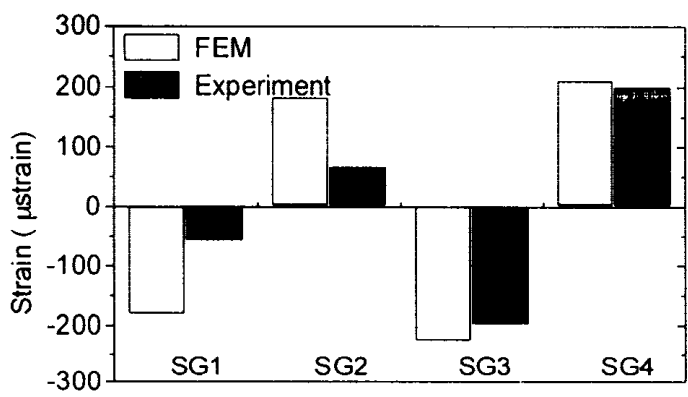

(b) Mode 12

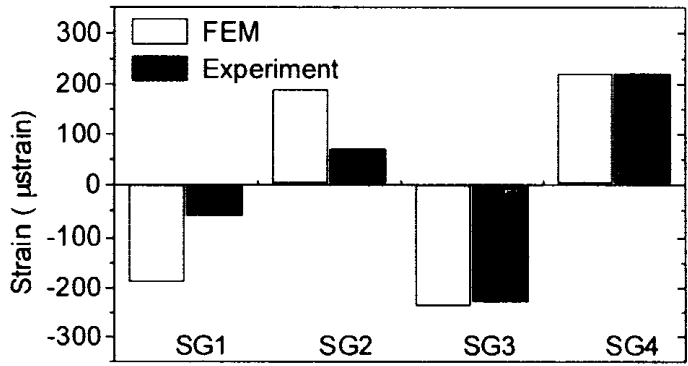

(c) Mode I3

Fig. 11 Strains obtained by experiment and FEM

の変化はわずかである。こういった傾向は、ステムと ピンのひずみに対し，実験上FEMの両方で見られる。し かし，ステムに発生するひずみ心方は実験值と FEM 值 で大きな開きが見られるのに対し，ビンのひずみの方 は両者がよい一致を示している，以上け結果から，FEM を用いて仮骨の特性を推定する場合は，ビンで測定さ れたひずみを用いる方がより望ましいと考えられる。

\section{4. 結 言}

本研究の結果をまとめると以下のようになる.

仮骨のヤング率が小さい領域では，ヤン薪の変化 に対してステムに生じるひずみの感度が高い。このこ とは，骨折治癒過程の前半において仮骨部の力学的特 性の推定が特に精度よく行える可能性があることを示 唆している.

またここの領域では仮骨部けボアソン比の值が創外 固定器に発生するひずみに与える影響が大きいため, これを考慮に入れた推定法が必要と考えられる。大ま かな推定は，沬り理論でも可能であるが，ヤング率が

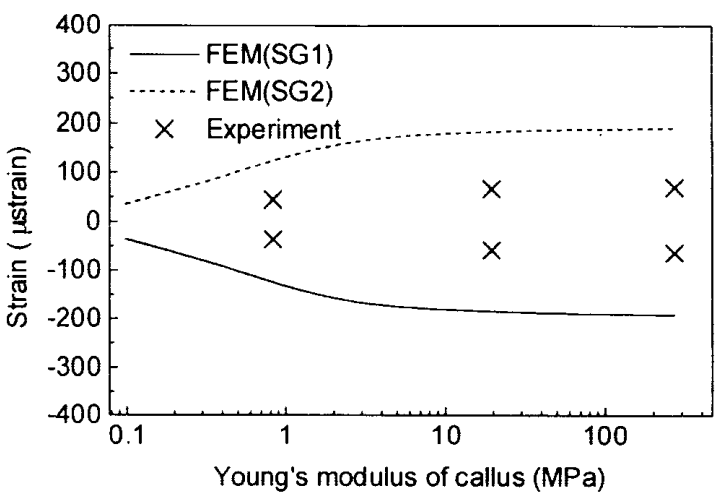

(a) Stem

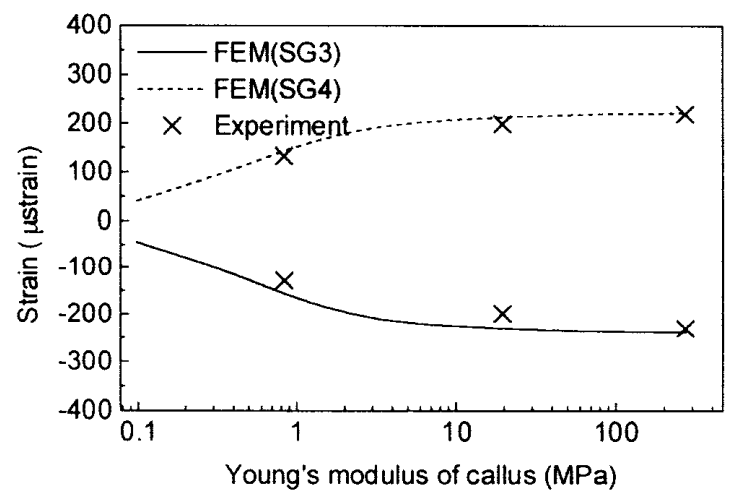

(b) Pin

Fig. 12 Strains with changing of the callus Young's modulus

低い領域で正確な推定を行う場合は，FEMを用いた方法 がより望ましい。

骨延長器を利用した方法に扔いては，ステムやヒン に生じるひ寺みは，実験値と解析值でその傾向は似か 奇っておうり，ピンのひずタを用いた推定の方がより精 度がよいことが明らかになった。しかし，ステムのひ 寸゙みには両者に開きが見られ，ステムのひずみを基に 仮骨り特性推定を行うには，より詳細なFEM モデルが 必要であると考えられる。

な技本研究は文部省科研費基盤研究 $(\mathrm{A})(2)$ (No.07405007)によるものであり，ここにその関倸機 関に謝意を表打る。

\section{参考文献}

（1）平澤・井上, 整形外科 MOOK（増刊 2-B1993）

（2）野村・中土, 整形外科バイオメカニクス (Vol. 13, 1991)

(3) 西村・ほか 2 名, 日本臨床バイオメカニクス学会 誌 (Vol.15, 1994)

(4) 浜谷・ほか 5 名, 北信越学生会 第 26 回学生員 卒業研究発表講演会 講演論文集 (1997)

(5) 酒井・ほか4 名, 第8回バイオェンジニアリング 学術講演会・夏季セミナー 講演論文集 (1997) 